\title{
Data report: calcareous nannofossil biostratigraphy of Expedition 330, Louisville Seamount Trail, Sites U1372-U1377'
}

\author{
Johnathon P. Kell ${ }^{2}$ and David K. Watkins ${ }^{3}$
}

\section{Chapter contents}

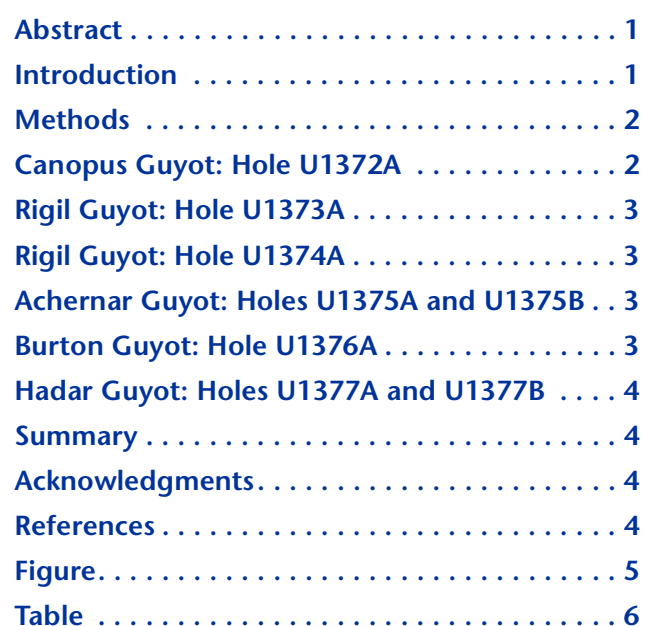

${ }^{1}$ Kell, J.P., and Watkins, D.K., 2014. Data report: calcareous nannofossil biostratigraphy of Expedition 330, Louisville Seamount Trail, Sites U1372-U1377. In Koppers, A.A.P., Yamazaki, T., Geldmacher, J., and the Expedition 330 Scientists, Proc. IODP, 330: Tokyo (Integrated Ocean Drilling Program Management International, Inc.). doi:10.2204/iodp.proc.330.201.2014

2Paleo-Data, Inc., 6619 Fleur de Lis Drive, New Orleans LA 70124, USA. jkell.nanno@gmail.com ${ }^{3}$ Department of Earth and Atmospheric Sciences, University of Nebraska-Lincoln, 214 Bessey Hall, Lincoln NE 68588-0340, USA.

\section{Abstract}

Six sites were drilled along the Louisville Seamount Trail during Integrated Ocean Drilling Program (IODP) Expedition 330. Pelagic sediments were recovered at four of the six sites, although calcareous nannofossils are observed at all sites. Sediments recovered at Site U1372 are Pliocene to Pleistocene in age. At Site U1373, only a small amount of disturbed pelagic sediment was recovered from the core catcher and was found to be early Pleistocene in age. Site U1374 has an early Pleistocene pelagic cap overlying older rocks, including sandstone that contains nannofossils from the late Maastrichtian (latest Cretaceous). Site U1375 contains indurated sediments that are early Paleocene in age, with the overlying pelagic sediments of Pliocene to Pleistocene age. Three distinct chalks were recovered at Site U1376. Each chalk had a unique assemblage of flora: Sample 330-U1376A-1R-1, 1 $\mathrm{cm}$, contains a mixed Neogene assemblage, the chalk of Sample 1R-1, $41 \mathrm{~cm}$, contains a late Miocene assemblage, and chalk from Sample 1R-1, $76 \mathrm{~cm}$, contains an assemblage of flora indicating an early to middle Miocene age that includes Sphenolithus heteromorphus. Only a small amount of disturbed sediment was recovered within the core catcher of Hole U1377A. The mixed assemblage within this sample is Pleistocene in age. In Hole U1377B, Sample 330-U1377B-1R-2, 0-1 cm, contains a middle Eocene assemblage that includes Discoaster barbadiensis, Discoaster binodosus, Discoaster saipanensis, Ericsonia formosa, and Chiasmolithus grandis.

\section{Introduction}

The Louisville Seamount Trail is a submarine structure in the Southwest Pacific Ocean that is $\sim 4300 \mathrm{~km}$ in length. The trail formed in response to the movement of the Pacific plate over the Louisville hotspot, tracing the plate's linear direction of movement. This line of submarine guyots terminates against the Tonga-Kermadec Trench, where this part of the Pacific plate is being subducted under the Indo-Australian plate.

Integrated Ocean Drilling Program (IODP) Expedition 330 sought to gain a greater understanding of motion among hotspots, true polar wander, and patterns of convection within the Earth's mantle (see the "Expedition 330 summary" chapter [Expedition 330 Scientists, 2012]). Six sites (IODP Sites U1372-U1377) were drilled into the top of seamounts along the Louisville Seamount Trail 
during the expedition (Fig. F1). Four of the six sites recovered a thin $(6.6-13.5 \mathrm{~m})$ layer of pelagic ooze capping the igneous rocks of the seamounts. In an effort to maximize core recovery in these sedimentary sections, a gravity-push method using the weight of the drill string with little or no rotation of the rotary core barrel assembly was employed. No pelagic ooze was encountered at Sites U1373 and U1376, as the holes were spudded directly into cobble-rich hardgrounds. The majority of the sedimentary section at all sites is composed of volcanic sandstone along with varying basalt breccia/ conglomerates. Frequently, these clastic sediment packages are mixed with basaltic lava flows and various other volcanic products.

\section{Methods}

The calcareous nannofossils discussed here were examined in smear slides prepared using microscope slides and coverslips that were mounted with Norland optical adhesive. These slides were observed using standard light microscope techniques on a Zeiss Photoscope 3 with cross-polarized and plane-transmitted light at 1000x magnification. A minimum of two traverses were examined for each sample, one in cross-polarized light and another in plane-transmitted light, with additional scanning of the slide for rare specimens. The zonation of Okada and Bukry (1980) was applied for Cenozoic calcareous nannofossils, whereas the zonation of Sissingh (1977) was used for the Upper Cretaceous. Taxonomy follows that of Bown (1998) and Perch-Nielsen (1985), where full taxonomic lists can be found. Complete lists of species identified by sample can be found in Table T1.

Estimates of the abundance of calcareous nannofossils were determined as follows:

$\mathrm{D}=$ dominant $(>100$ specimens per field of view).

$\mathrm{A}=$ abundant $(>10-100$ specimens per field of view).

$\mathrm{C}=$ common (1-10 specimens per field of view).

$\mathrm{F}=$ few (1 specimen per 1-10 fields of view).

$\mathrm{R}=$ rare $(<1$ specimen per 10 fields of view $)$.

$\mathrm{B}=$ barren.

Preservation of calcareous nannofossils was classified as follows:

$\mathrm{VG}=$ very good (no evidence of dissolution and/or recrystallization, no alteration of primary morphological characteristics, and all specimens identifiable to the species level).

$\mathrm{G}=\operatorname{good}$ (little or no evidence of dissolution and/or recrystallization, primary morpho- logical characteristics only slightly altered, and specimens identifiable to the species level).

$\mathrm{M}$ = moderate (some etching and/or recrystallization, primary morphological characteristics somewhat altered, and most specimens identifiable to the species level).

$\mathrm{P}$ = poor (severe etching or overgrowth, primary morphological characteristics largely destroyed, fragmentation has occurred, and specimens often unidentifiable at the species and/or generic level).

\section{Canopus Guyot: Hole U1372A}

Drilling at Canopus Guyot recovered three cores containing pelagic sediment. This sediment was soupy in nature, requiring the core liner to be perforated and stood on end to allow excess water to drain before curation. This treatment may have allowed movement of nannofossils through the length of the core and resulted in a degree of homogenization of the assemblages. In general, the pelagic cap recovered from Hole U1372A contains nannofossil assemblages of Neogene age.

Sediment from Cores 330-U1372A-1R through 5R were examined for calcareous nannofossil content. In general, two samples were examined in each section (Table T1). All nannofossil samples examined exhibit very good to good preservation. Core $1 \mathrm{R}$ is only $10 \mathrm{~cm}$ long and is thought to have been recovered at the mudline. Small Gephyrocapsa spp. dominate the assemblage. The presence of Pseudoemiliania lacunosa indicates a Pleistocene age, assigned to Zone CN14.

Thirteen samples were examined from Core 330U1372A-2R. Small gephyrocapsids compose the majority of the assemblage. $P$. lacunosa is present throughout Core $2 \mathrm{R}$, and this species, together with the absence of discoasters, indicates Zones CN13CN14 (early Pleistocene).

Sample 330-U1372A-3R-1, 0-1 cm, contains the first observed discoasters, including Discoaster brouweri, Discoaster tamalis, and Discoaster variabilis. These cooccur with Sphenolithus abies and Reticulofenestra pseudoumbilicus. The last appearance datum (LAD) of the latter taxon marks the top of Zone CN11. This assemblage persists through the base of Core 3R, which is assigned to Zone CN11 (Pliocene).

Samples from the matrix of the volcanic breccia/conglomerates in Cores 330-U1372A-4R and 5R were barren or composed of very rare, long-ranging specimens that were not age diagnostic. 


\section{Rigil Guyot: Hole U1373A}

Despite pelagic sediment observed during seafloor observation before spudding the hole, almost none was recovered. The very small amount of material in the core catcher is assumed to have settled out from the seawater in the core liner and likely represents the unsampled oozy sediment observed during seafloor observation. The assemblage contains Neogene background species Helicosphaera carteri and Calcidiscus leptoporus. Common species include small Gephyrocapsa and P. lacunosa. Rare specimens of Gephyrocapsa caribbeanica $(>4 \mu \mathrm{m})$ were also observed, the first occurrence of which marks the base of Zone CN13. Based on the presence of G. caribbeanica ( $>4$ $\mu \mathrm{m})$ and $P$. lacunosa, as well as the disturbed nature of the recovered sediment, a range of Zones CN13CN14 is assigned to this sediment.

Additional samples from the volcanic breccias and conglomerates are barren of nannofossils with the exception Sample 330-U1373A-1R-3, 14-16 cm, which contains an assemblage of long-ranging taxa (Table T1); however, the continued presence of $P$. lacunosa and small Gephyrocapsa and absence of discoasters suggests a similar zonal assignment of Zones CN13-CN14 (early Pleistocene).

\section{Rigil Guyot: Hole U1374A}

Hole U1374A was the second site to be drilled on Rigil Guyot. The first core contained $6.64 \mathrm{~m}$ of unconsolidated pelagic sediment, with an additional $0.62 \mathrm{~m}$ of volcanic sandstone at the bottom. Eleven samples were examined through the interval of pelagic sediment (Table T1). The first sample (330U1374A-1R-1, 99-100 cm) contains Ceratolithus cristatus and $G$. caribbeanica, with an assemblage of long-ranging background flora, suggesting an age no older than Pleistocene. Sample 1R-2, 130-131 cm, contains the LAD of Helicosphaera sellii, and Sample 1R-3, 99-100 cm, contains the LAD of Calcidiscus macintyrei, which both occur within Subzone $\mathrm{CN13b}$. These taxa persist to the base of the pelagic sediment, and no discoasters were observed in any of the samples, indicating that the base of the pelagic cap recovered in Hole U1374A contains calcareous nannofossil assemblages of early Pleistocene age (Zone CN13).

Indurated sandstone from Samples 330-U1374A-3R$1,30 \mathrm{~cm}$, and 3R-1, $70 \mathrm{~cm}$, contain nannofossils in rare abundances from the Upper Cretaceous. The sample at $30 \mathrm{~cm}$ has a lower species richness than the sample at $70 \mathrm{~cm}$ (11 species versus 17 species, re- spectively), both contain Upper Cretaceous species including Prediscosphaera cretacea, Prediscosphaera spinosa, Arkhangelskiella specillata, Eiffellithus turriseiffelii, Micula decussata, Microrhabdulus belgicus, and Nephrolithus frequens, indicative of Zone CC26 (late Maastrichtian).

\section{Achernar Guyot: Holes U1375A and U1375B}

Hole U1375A was thought to have recovered $8.5 \mathrm{~m}$ of pelagic sediment that was flushed away during the rotary core barrel drilling process, leaving only a small amount of disturbed sediment in the core catcher. This sample contains a mixed assemblage of nannofossils that includes $C$. macintyrei and $H$. sellii, indicative of Pliocene to early Pleistocene age sediments (Table T1).

Scrapings were taken with a razor blade from the indurated sedimentary matrix of the volcanic breccia in Section 330-U1375A-2R-1. Sample 2R-1, $32 \mathrm{~cm}$, is nearly barren, with a single specimen of Coccolithus pelagicus observed. Sample 2R-1, $13 \mathrm{~cm}$, contains rare specimens of Prinsius bisulcus, Prinsius dimorphosus, and Prinsius martinii, indicating an early Paleocene age.

A sample taken from the core catcher of Core 330U1375B-1R contains only rare Pliocene to Pleistocene nannofossils (Table T1).

\section{Burton Guyot: Hole U1376A}

During visual reconnaissance for Hole U1376A, the subsea camera showed no pelagic sediment present in the immediate area. Although no pelagic sediments were recovered, 11 samples were examined from Site U1376. Eight samples collected by scraping material from the indurated sedimentary matrix of a volcanic sandstone and a limestone proved to be barren of nannofossils (Table T1). Three additional samples that contain nannofossils were taken from three chalks within Section 330-U1376A-1R-1. Sample $1 \mathrm{R}-1,1 \mathrm{~cm}$, contains a mixed Neogene assemblage that includes $S$. abies, C. leptoporus, Calcidiscus tropicus, Discoaster neohamatus, and Discoaster deflandrei. Sample 1R-1, $41 \mathrm{~cm}$, contains an assemblage composed of Amaurolithus primus, Amaurolithus delicatus, Amaurolithus tricorniculatus, and Discoaster loeblichii. The LAD of D. loeblichii falls within Subzone $\mathrm{CN} 9 \mathrm{a}$ and the first appearance datum of the genus Amaurolithus marks the base of Subzone CN9b, suggesting that the chalk was deposited during the latest 
Tortonian (late Miocene). Sample 1R-1, $76 \mathrm{~cm}$, contains frequent Sphenolithus heteromorphus, indicating an early to middle Miocene age (Zones CN3-CN4).

\section{Hadar Guyot: Holes U1377A and U1377B}

Two holes were drilled at Hadar Guyot. In Hole U1377A, only a small amount of disturbed sediment was recovered in the core catcher of the first core. The majority of the mixed assemblage within this sample is composed of Pleistocene-age nannofossils, including small Gephyrocapsa and P. lacunosa. The assemblage also includes older, presumably reworked taxa, including D. brouweri and Discoaster triradiatus (late Miocene to Pliocene), as well as D. neohamatus (late Miocene). Two additional samples were taken from Section 330-U1377A-2R-1. Sample 2R-1, $8 \mathrm{~cm}$, contains a single specimen of Cyclicargolithus floridanus (late Eocene to middle Miocene) along with a single specimen of the long-ranging Mesozoic species Watznaeuria barnesiae; their presence may be the result of contamination. Sample 2R-1, $13 \mathrm{~cm}$, contains a single specimen each of the Cenozoic taxa $C$. pelagicus and Dictyococcites productus.

Four samples were taken from the Hole U1377B. Sample 330-U1377B-1R-2, 0-1 cm, contains an Eocene assemblage including Discoaster barbadiensis, Discoaster binodosus, Discoaster saipanensis, Ericsonia formosa, and Chiasmolithus grandis, which suggest a middle Eocene age. The remaining three samples were taken from Section 1R-2. Sample 1R-2, $7 \mathrm{~cm}$, contains only two species that are not age diagnostic (D. productus and C. floridanus). Sample $1 \mathrm{R}-2,28 \mathrm{~cm}$, contains a mixed assemblage of late Miocene to Pleistocene nannofossils including C. macintyrei, Discoaster surculus, D. tamalis, and small Gephyrocapsa and could represent contamination. The final sample $(1 \mathrm{R}-2,29 \mathrm{~cm})$ is barren of nannoflora.

\section{Summary}

Drilling at six sites during Expedition 330 recovered sediments from the Upper Cretaceous (upper Maastrichtian) to Pleistocene. Pelagic sediment was recovered at four of the six sites, although calcareous nannofossils are present at all sites. Sediments recovered at Site U1372 are Pliocene to Pleistocene in age. At Site U1373, a small amount of disturbed pelagic sediment of early Pleistocene age was recovered within the core catcher. Site U1374 has an early Pleistocene pelagic cap overlying older sediment, including sandstone that contains nannofossils of late Maas- trichtian (latest Cretaceous) age. Indurated sediments sampled from Site U1375 contain nannofossils indicative of the early Paleocene, whereas the overlying pelagic sediments are Pliocene to Pleistocene in age. At Site U1376, three distinct chalks were recovered; each chalk contains a unique assemblage of nannofossils. Sample 330-U1376A-1R-1, $1 \mathrm{~cm}$, contains a mixed Neogene assemblage. Sample 1R-1, $41 \mathrm{~cm}$, contains a late Miocene assemblage, whereas Sample 1R-1, $76 \mathrm{~cm}$, contains $S$. hetermorphus, indicative of the early to middle Miocene. At Site U1377, a small amount of disturbed sediment was recovered within the core catcher of Hole U1377A, which contains a mixed assemblage that is likely Pleistocene in age. In Hole U1377B, Sample 330-U1377B-1R-2, 0-1 $\mathrm{cm}$, contains a middle Eocene assemblage that includes D. barbadiensis, D. binodosus, D. saipanensis, E. formosa, and C. grandis.

\section{Acknowledgments}

The first author wishes to thank Dr. David K. Watkins for helpful comments and reviews of early drafts of this paper. We also wish to thank Dr. Denise Kulhanek for a helpful external review of the final draft. Samples were provided by the Integrated Ocean Drilling Program (IODP). Funding was provided by the National Science Foundation.

\section{References}

Bown, P.R. (Ed.), 1998. Calcareous Nannofossil Biostratigraphy: Dordrecht, The Netherlands (Kluwer Academic Publ.).

Expedition 330 Scientists, 2012. Expedition 330 summary. In Koppers, A.A.P., Yamazaki, T., Geldmacher, J., and the Expedition 330 Scientists, Proc. IODP, 330: Tokyo (Integrated Ocean Drilling Program Management International, Inc.). doi:10.2204/iodp.proc.330.101.2012

Okada, H., and Bukry, D., 1980. Supplementary modification and introduction of code numbers to the low-latitude coccolith biostratigraphic zonation (Bukry, 1973; 1975). Mar. Micropaleontol., 5:321-325. doi:10.1016/ 0377-8398(80)90016-X

Perch-Nielsen, K., 1985. Cenozoic calcareous nannofossils. In Bolli, H.M., Saunders, J.B., and Perch-Nielsen, K. (Eds.), Plankton Stratigraphy: Cambridge (Cambridge Univ. Press), 427-554.

Sissingh, W., 1977. Biostratigraphy of Cretaceous calcareous nannoplankton. Geol. Mijnbouw, 56:37-65.

Initial receipt: 20 October 2013

Acceptance: 30 April 2014

Publication: 31 July 2014

MS 330-201 
Figure F1. Expedition 330 site map. IODP = Integrated Ocean Drilling Program.

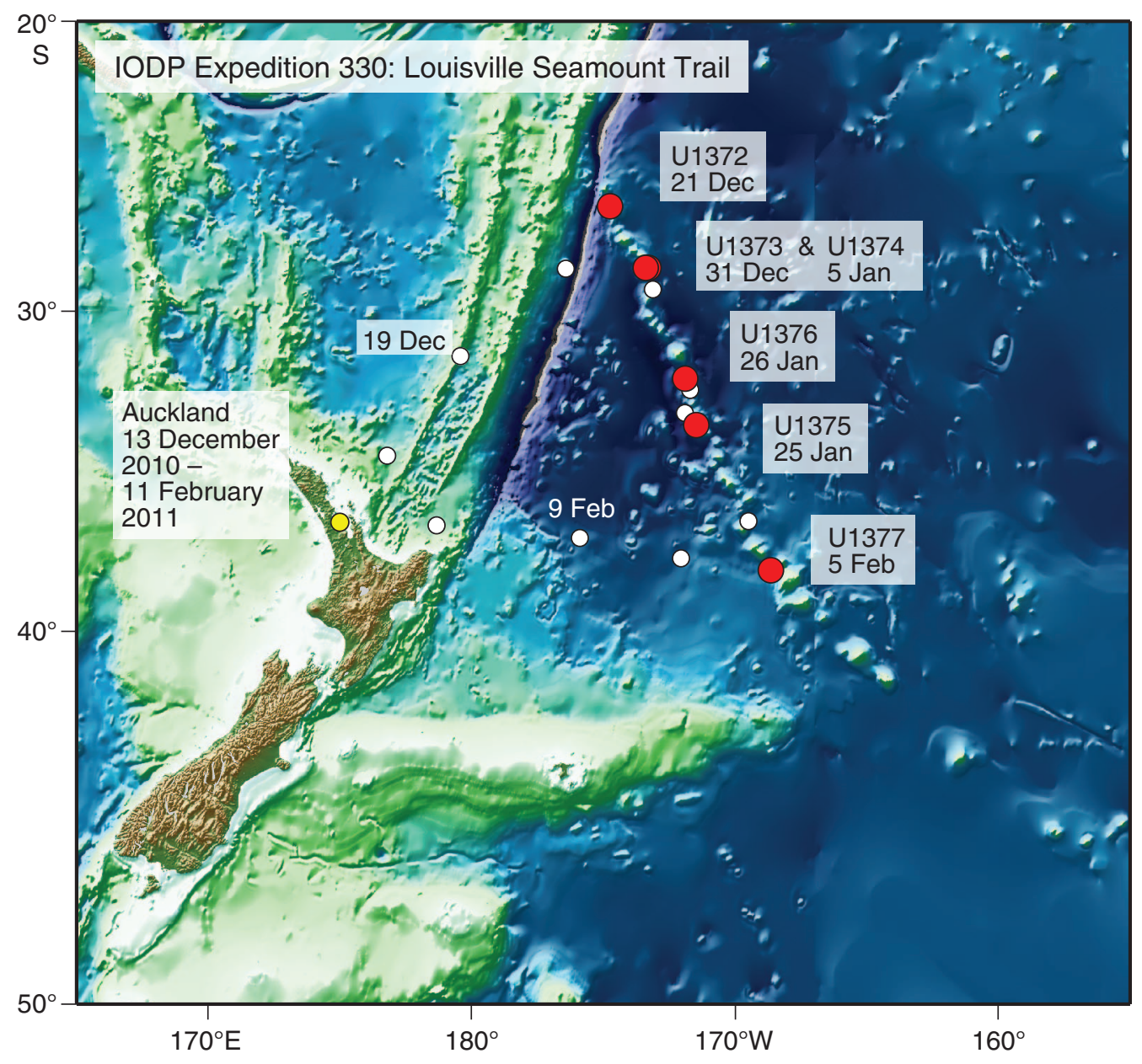


Table T1. Nannofossil assemblages. This table is available in an oversized format. 